\title{
Volume-frequency distributions of marine phytoplankton in a temperate neritic environment
}

\author{
Louis A. Hobson \\ Department of Biology, University of Victoria, Victoria, British Columbia, Canada V8W 2Y2
}

\begin{abstract}
A seasonal study was carried out to determine whether or not volume-frequency distributions of near surface nano- and microplankton were approximated by a power function model in temperate neritic waters. Measurements of buoyancy frequency, the nutrients $N_{3}-N, N O_{2}-N, N H_{4}-N$, urea-N, $\mathrm{Si}(\mathrm{OH})_{4}-\mathrm{Si}$, and $\mathrm{PO}_{4}-\mathrm{P}$, phytoplankton photosynthetic pigments, and cell concentrations and volumes were made around a frontal zone in the Strait of Georgia, Canada, at ca 3 wk intervals from April 1983 to September 1984, excluding October to February. The model accounted for a large percentage of the variance in spectra when nano-flagellates and dinoflagellates dominated phytoplankton crops in pre-diatom bloom and nutrient-depleted waters. When diatoms dominated crops, the fit was better in summer than in spring and often was positively correlated to temperature. Possible covariance of temperature and grazing by large omnivorous zooplankters on diatoms was considered. The exponent of the power function varied around -0.92 , derived from linear regression analysis of a $\log _{e^{-}}$ transformed allometric equation. A geometric mean or functional regression slope was used because the slope varied with the correlation coefficient and because the relationship describes an allometric dependence. Results support the use of a power function model to predict volume-frequency spectra of temperate neritic phytoplankton whenever diatoms are not abundant or from the time of the demise of the spring diatom bloom until at least the early fall season when diatoms are abundant. The presence of diatoms such as Lauderia borealis, Skeletonema costatum, and Thalassiosira nordenskiöldii in larger numbers than predicted by their cell volumes invalidates use of the model during spring.
\end{abstract}

\section{INTRODUCTION}

Seston particles in the sea usually increase in number as their volumes decrease (e.g. Sheldon \& Parson 1967). The resultant volume-frequency distributions often appear to be exponential, particularly in the oceanic realm (Sheldon et al. 1972). This distribution suggests that phytoplankton assemblages are structured because a large fraction of seston particles in the acean are plant cells (Hobson et al. 1973). Structure can result simply from a volume-scaled intrinsic division rate with negative exponent (Banse 1976) operating on an assemblage of cells with varying cellular volume of constant frequency. However, this model produces volume-frequency distributions characterised by an infinite number of different negative slopes. Platt \& Denman $(1977,1978)$ solved this problem for a model encompassing a much larger volume range than exhibited by algal assemblages by assuming that steady state balance occurred between production and grazing of daughter cells and metabolic losses. This leads to a unique solution for the slope of volume-frequency distributions. Alternately, if intrinsic division rates of algal cells are not volume scaled (Banse 1982), a model could be based on volume-scaled rates of predation by herbivores and omnivores and cell sinking. Because of the uncertainty in scaling intrinsic rates of algal cell divison, it is difficult to choose a theoretical approach to use when examining the structure of phytoplanktonic assemblages. This gap in our understanding of phytoplankton dynamics needs to be filled because a model could provide a powerful tool to predict productivity and biomass of phytoplankton in aquatic ecosystems (e.g. Borgmann 1982, Platt et al. 1984, Sprules \& Munawar 1986). Further, phytoplankton assemblages do exhibit regular structure, which begs to be explained.

Field studies of mass-frequency distributions of phytoplankton and zooplankton assemblages in the open ocean (Platt et al 1984, Rodriguez \& Mullin 1986, Sprules \& Munawar 1986) and lakes (Sprules \& Munawar 1986) have shown them to be in accordance with the model derived by Platt \& Denman (1977, 1978). However, I know of no studies carried out in a 
highly variable inshore environment where steady state conditions may not be the rule. My preliminary observations based on studies of nano- and microphytoplankton carbon in a temperate fjord (Hobson $1981,1983)$ suggest that volume-frequency distributions do not conform to a power function model, at least during the spring diatom increase. These observations were tested by examining the volume-frequency structure of phytoplankton crops in waters of the Strait of Georgia, Canada, and the results are presented in this communication.

\section{METHODS AND MATERIALS}

Organisms in the Strait of Georgia were investigated because these waters contain many tidally driven fronts separating stratified from well-mixed waters (Parsons et al. 1981). These fronts are seasonally stable and provide contrasting physical, chemical, and biological properties. Because of these steep gradients a large data base can be accumulated in a relatively short time.

Eighteen cruises of the MSSV 'John Strickland' to the waters of southeastern Vancouver Island (Fig. 1) were completed at approximately $3 \mathrm{wk}$ intervals from April 1983 to September 1984, excluding the months from October to February. Conductivity, temperature, and depth (pressure) were monitored throughout the area with an Applied Microsystems CTD coupled to a 'fish', either towed horizontally or lowered vertically from the sea surface to $20 \mathrm{~m}$. The 'fish' contained a deep-well submersible pump for simultaneous collection of seawater samples, for determination of nutrients and photosynthetic pigments, and for taxonomic and ataxonomic composition of nano- and micro-plankton assemblages. The positions of vertical stations were set by the distribution of chlorophyll pigments, which were measured by in vivo fluorescence of seawater pumped through a Turner fluorometer. Stations were usually located on either side of and within a phytoplankton patch extending from the sea surface to at least $10 \mathrm{~m}$, which most often was found in northern Saanich Inlet and Satellite Channel, bounded to the south by central and southern Saanich Inlet and to the east by Haro Strait waters (Fig. 1).

Salinity and temperature data were converted to densities $(\rho)$, which were recorded for either 0.25 or 0.5 $\mathrm{m}$ depth intervals from 0 to $20 \mathrm{~m}$. Values of $\rho$ were used to calculate buoyancy frequency, which is a major indicator of stability in the water column (e.g. Turner 1981) between each depth interval:

$$
N=\{g / \rho \mathrm{d} \rho / \mathrm{d} z\}^{1 / 2}
$$

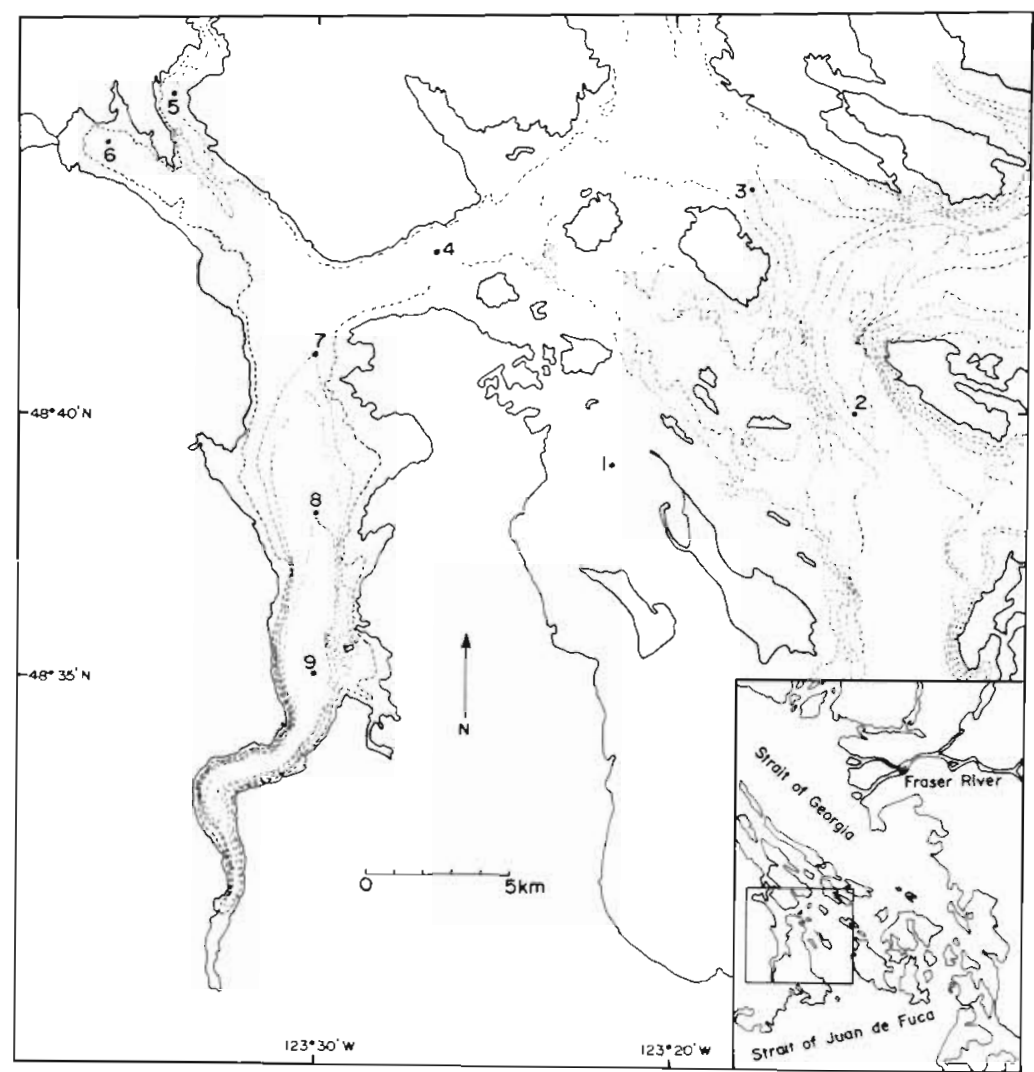

Fig. 1 Waters of southwestern Vancouver Island, Canada, showing Sidney Channel (1), Haro Strait (2), Swanson Channel (3), Satellite Channel (4), Sansum Narrows (5), Cowichan Bay (6), and northern (7), centra] (8) and southern (9) Saanich In]et. Depth contours are at $40 \mathrm{~m}$ intervals 
where $N=$ buoyancy frequency (radians $\mathrm{s}^{-1}$ ) $; g=$ gravitational acceleration $\left(9.8 \mathrm{~m} \mathrm{~s}^{-2}\right) ; z=$ depth $(\mathrm{m})$.

Nutrient samples were collected at $2 \mathrm{~m}$ intervals from the sea surface to $20 \mathrm{~m}$, filtered through nitex netting $(66 \mu \mathrm{m})$ and immediately frozen. Storage of frozen samples did not exceed $2 \mathrm{wk}$. The nutrients $\mathrm{NO}_{3}-\mathrm{N}$, $\mathrm{NO}_{2}-\mathrm{N}$ and reactive $\mathrm{PO}_{4}-\mathrm{P}$ and $\mathrm{Si}(\mathrm{OH})_{4}-\mathrm{Si}$ were analysed by standard spectrophotometric methods (Strickland \& Parsons 1972). Inorganic $\mathrm{N}^{2} \mathrm{NH}_{4}-\mathrm{N}$ was measured with the technique described by Solorzano (1969), and organic $\mathrm{N}$ as urea- $\mathrm{N}$ was assessed by the urease method (McCarthy 1970).

Photosynthetic pigments, including chlorophyll a and pheopigments, were estimated spectrophotometrically in $90 \%$ acetone extracts by the method of Lorenzen (1967). When pheopigments were absent, other chlorophyll species were estimated by the trichromatic equations derived by Jeffrey \& Humphrey (1975). Measurements made by in vivo fluorometry were most highly correlated to total chlorophyll pigments, including pheopigments (results not shown), rather than to just chlorophyll $a$.

Samples treated with Lugol's acetic acid-iodine preservative were examined with an inverted microscope to determine taxonomic composition, cell numbers and volumes (converted to carbon by the ratios of cellular carbon to volume described by Strathmann 1967) of phytoplankton crops. This method allowed enumeration of cells with dimensions as small as $2 \mu \mathrm{m}$. Percentages of total phytoplankton volume due to diatoms, dinoflagellates, and unidentified flagellated cells were calculated. The degree of conformation of the volumefrequency data to

$$
\mathrm{F}=\mathrm{a} \mathrm{V}^{\mathrm{b}}
$$

was evaluated by linear regression analysis of the logarithmic transformation of the foregoing expression to:

$$
\ln \mathrm{F}=\ln a+b \ln \mathrm{V}
$$

where $\mathrm{F}=$ number of individuals (cells ${ }^{-1}$ ) of a given cellular volume $\left(\mathrm{V}, \mathrm{um}^{3} \mathrm{cell}^{-1}\right)$; $a$ and $b=$ proportionality constant and slope of the line, respectively. This treatment produces a normalized spectrum with slope comparable to other values (e.g. Platt \& Denman 1978). When the regression analysis was statistically significant $(p \leq 0.05)$, the value of $b$ was recorded as a quantitative indicator of the volume-frequency structure of the algal assemblage. However, because $r$ and $b$ were significantly correlated ( $r=0.83, p<0.01, n=11)$, and because both independent and dependent variables exhibit natural uncertainty, this correlation was removed by using a geometric mean functional regression such that the slope $b$ is replaced by $v=b / r$. The use of the functional regression is also recommended for determining allometric relations as in this case (Ricker 1973).

\section{RESULTS}

Variations in physical, chemical and biological properties in the near-surface layer (0 to $5 \mathrm{~m}$ ) of the wellmixed water of Haro Strait, the frontal zone in Satellite Channel and the stable water of Saanich Inlet are summarized in Fig. 2. Heat contents were maximal and minimal in Saanich Inlet and Haro Strait, while salinities were the inverse. There was some evidence for the appearance of relatively low salinity water throughout the region in late August, perhaps due to Fraser River water, but no definitive comment can be made. Concentrations of $\mathrm{NO}_{3}^{-}+\mathrm{NO}_{2}-\mathrm{N}$ were always largest and smallest in Haro Strait and Saanich Inlet, and were paralleled by those of $\mathrm{Si}(\mathrm{OH})_{4}-\mathrm{Si}$ and $\mathrm{PO}_{4}-\mathrm{P}$. Values of $\mathrm{NO}_{3^{-}}+\mathrm{NO}_{2}-\mathrm{N}$ rarely exceeded $1 \mu \mathrm{m}$ in Saanich Inlet between mid-May and late August. During the latter part of this period, $\mathrm{NH}_{4}-\mathrm{N}$ concentrations exceeded those of $\mathrm{NO}_{3}-+\mathrm{NO}_{2}-\mathrm{N}$, while those of urea$\mathrm{N}$ were less than $0.35 \mu \mathrm{m}$ until at least early August (Table 1). The spring diatom bloom was observed in Saanich Inlet and frontal zone waters during early May. After the bloom, pigment concentrations were generally largest and smallest in the frontal zone and Saanich Inlet.

Clearly, temporal and spatial variations of phytoplankton crops were large. However, for the purpose of making generalizations about volume-frequency distributions in phytoplankton crops, observations were separated into 5 groups based on the near-surface $(0$ to $5 \mathrm{~m})$ concentration of plant carbon and taxonomic composition of assemblages (Table 2), and the vertical distributions $(0$ to $20 \mathrm{~m}$ ) of algal pigments, $\mathrm{NO}_{3}-\mathrm{N}$, and buoyancy frequency ( $N$ ) (Fig. 3). These groups included: (1) pre-diatom bloom waters in which concentrations of phytoplankton carbon were low, the relative mass of diatoms was small, chlorophyll concentrations, which were primarily chlorophyll $b$ in late spring (data not shown), were maximal near the sea surface even though values of $\mathrm{N}$ were small, and $\mathrm{NO}_{3}-\mathrm{N}$ concentrations were large and uniformly distributed over depth (Fig. 3A); (2) wellmixed waters that were similar to (1) except that larger concentrations of phytoplankton carbon, larger relative masses of diatoms, and chlorophyll concentrations, which were primarily due to chlorophyll a (data not shown), were uniformly distributed over depth (Fig. 3B); (3) near-surface bloom waters that were similar to (2) except for large near-surface chlorophyll concentrations, reduced near-surface $\mathrm{NO}_{3}$ $\mathrm{N}$ levels and maximum values of $N$ between depths of 6 and $13 \mathrm{~m}$ (Fig. 3C); (4) sub-surface bloom waters that were similar to (3) except for larger concentrations of chlorophyll in the subsurface than in the near-surface layer, and very low $\mathrm{NO}_{3}-\mathrm{N}$ concen- 


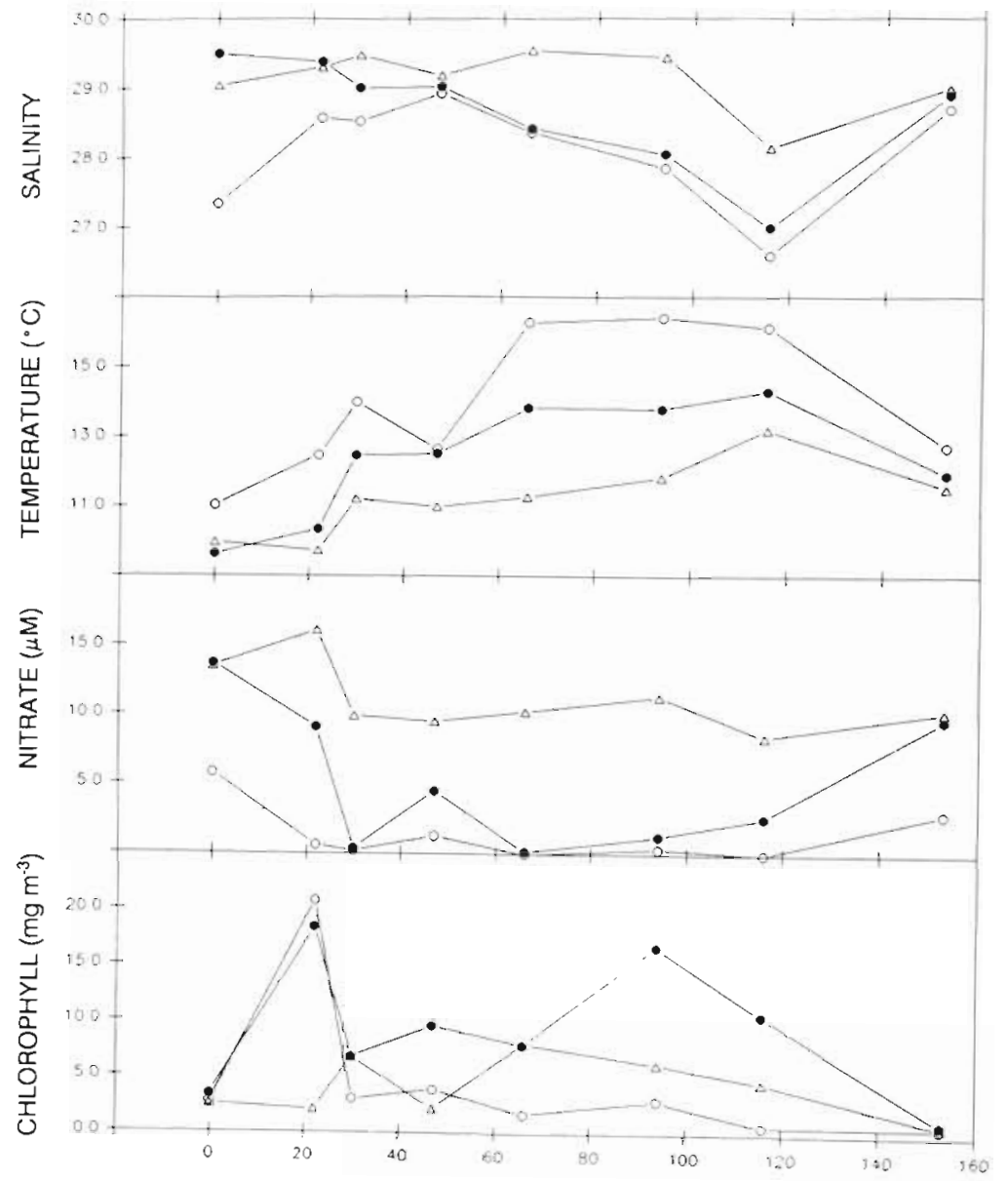

TIME (DAYS)
Fig. 2. Temporal variations in salinity, Temperature, $\mathrm{NO}_{3}-+\mathrm{NO}_{2}-\mathrm{N}_{1}$ and chlorophyll concentrations in near-surface $(0$ to $5 \mathrm{~m})$ waters of Haro Strait $(\Delta)$, Satellite Channel $(\bullet)$ and Saanich Inlet () after 20 Apr 1983 (time $=0$ d) trations in the near-surface Iayer (Fig. 3D); and (5) stripped waters where concentrations of phytoplankton carbon were low, the relative mass of diatoms was low, vertical distributions of chlorophyll were uniform, and $\mathrm{NO}_{3}-\mathrm{N}$ and $\mathrm{N}$ levels were low and high, respectively, throughout the water column (Fig. 3E).

The fit of volume-frequency spectra to a power func- tion model was variable (Fig. 4). The model accounted for between 20 and $67 \%$ of the variance in spectra when nano-flagellates and dinoflagellates dominated phytoplankton carbon in pre-bloom and nutrientstripped waters (Fig. 5A). When diatoms dominated crops, the model accounted for increasing percentages of the variance of distributions during summer (Fig

Table 1. Temporal variations of mean values and their standard deviations for concentrations of nitrogen in nitrate and nitrite ions $\left(\mathrm{NO}_{3}-\mathrm{N}\right)$, ammonia ions $\left(\mathrm{NH}_{4}-\mathrm{N}\right)$ and urea (urea-N) in the near-surface waters $(0$ to $5 \mathrm{~m}$ ) of Saanich Inlet after the spring diatom bloom

\begin{tabular}{|c|c|c|c|c|}
\hline Date & $\mathrm{NO}_{3}-\mathrm{N}(\mu M)$ & $\mathrm{NH}_{4}-\mathrm{N}(\mu M)$ & Urea-N $(\mu M)$ & $n$ \\
\hline 12 May 83 & $0.63 \pm 0.35$ & $0.34 \pm 0.30$ & $\mathrm{UD}^{\mathrm{a}}$ & 4 \\
\hline 30 May 83 & $0.21 \pm 0.15$ & $0.11 \pm 0.18$ & UD & 6 \\
\hline 16 Jun 83 & $1.5 \pm 0.91$ & $0.27 \pm 0.16$ & $0.33 \pm 0.58$ & 3 \\
\hline $5 \mathrm{Jul} 83$ & $0.03 \pm 0.01$ & $2.6 \pm 1.9$ & $0.15 \pm 0.27$ & 3 \\
\hline 2 Aug 83 & $0.51 \pm 0.30$ & $0.97 \pm 0.38$ & $0.15 \pm 0.16$ & 3 \\
\hline 24 Aug 83 & $0.06 \pm 0.02$ & $1.5 \pm 0.44$ & - & 3 \\
\hline 30 Sep 83 & $3.0 \pm 0.44$ & $1.6 \pm 0.52$ & - & 4 \\
\hline
\end{tabular}


Table 2. Mean values and their standard deviations for phytoplankton carbon (PC) and percentage of crop carbon due to diatoms (Dia) in pre-bloom (1), well-mixed (2), surface bloom (3). sub-surface chlorophyll maximum (4), and nutrientstripped (5) groups (Gr.) in near-surface (0 to $5 \mathrm{~m}$ ) waters

\begin{tabular}{|cccc|}
\hline Gr. & PC $\left(\mathrm{mg} \mathrm{m}^{-3}\right)$ & Dia $(\% \mathrm{PC})$ & $n$ \\
\hline 1 & $34 \pm 29$ & $8 \pm 6.5$ & 7 \\
2 & $219 \pm 202$ & $88 \pm 9.7$ & 17 \\
3 & $261 \pm 280$ & $82 \pm 10$ & 12 \\
4 & $266 \pm 243$ & $88 \pm 12$ & 4 \\
5 & $43 \pm 17$ & $19 \pm 16$ & 4 \\
\hline
\end{tabular}

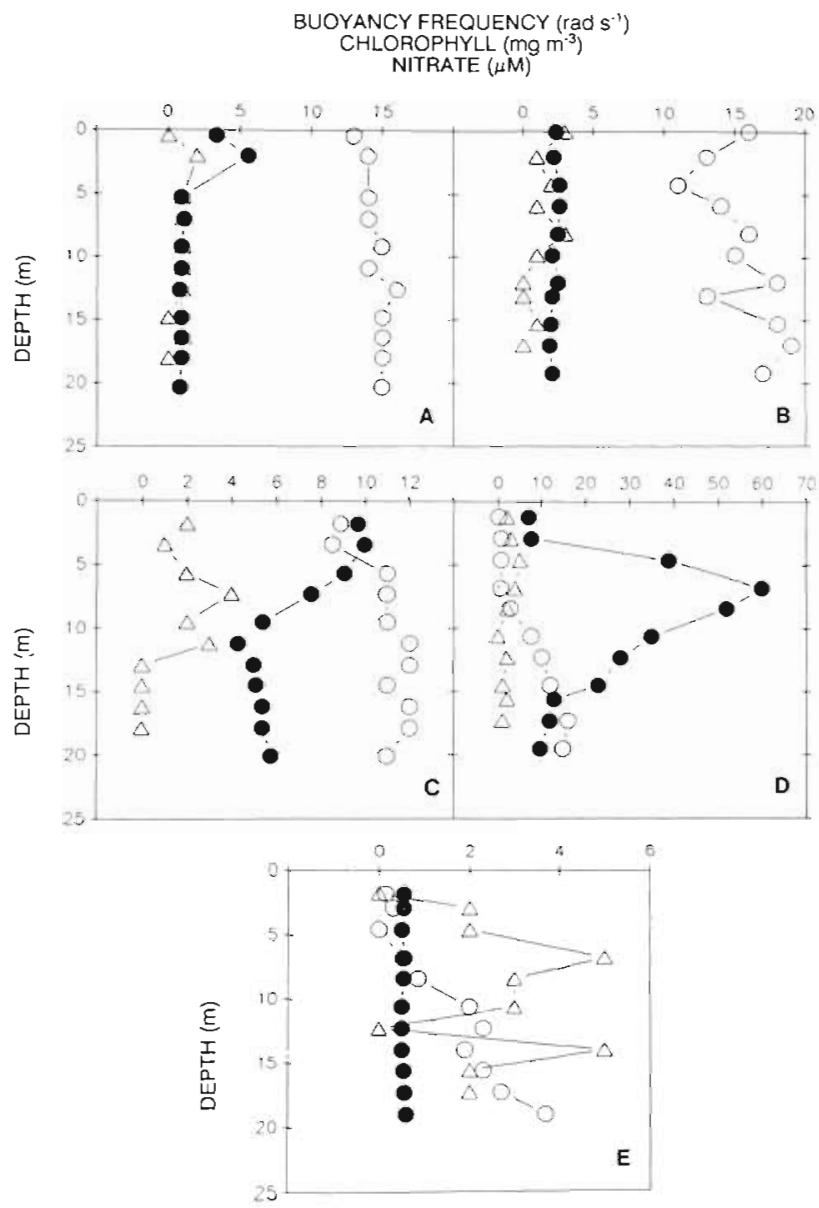

Fig. 3. Examples of distributions of buoyancy frequency $(\Delta)$, and $\mathrm{NO}_{3^{-}}+\mathrm{NO}_{2}-\mathrm{N}(\mathrm{O})$ and chlorophyll $(\bullet)$ concentrations with depth in (A) pre-diatom bloom, (B) well-mixed, (C) surface diatom bloom, (D) sub-surface diatom bloom, and (E) nutrient-stripped waters. Buoyancy frequency values are means for each $1 \mathrm{~m}$ depth interval

5B). Possible causes for the seasonality in fit between data and model were explored.

Qualitatively, during spring the diatoms Lauderia borealis Gran, Skeletonema costatum (Grevelle) Cleve, and Thalassiosira nordenskiöldii Cleve with cell vol-

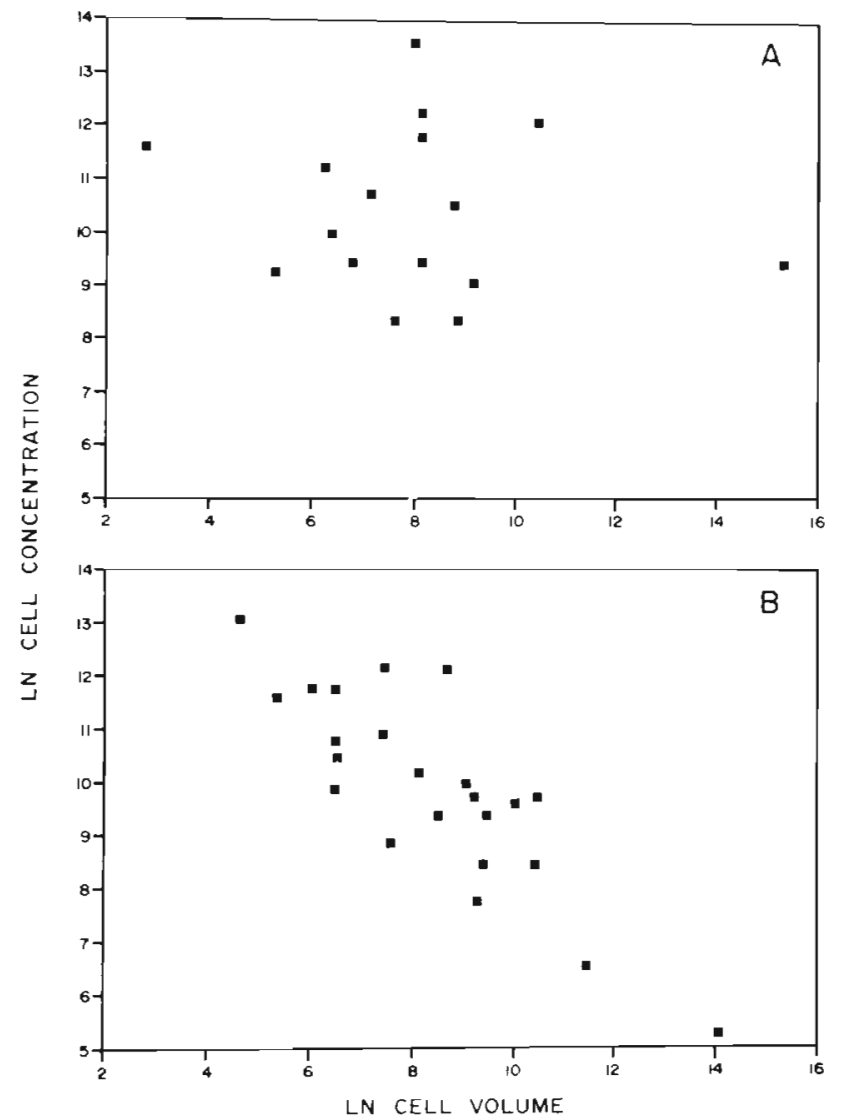

Fig. 4. The diversity of cell-volume frequencies illustrated by crop structures after (A) a diatom-bloom in central Saanich Inlet, mid-May 1983 and (B) a flagellate-bloom in northern Saanich Inlet, early August 1983

umes varying between $3 \times 10^{3}$ and $36 \times 10^{3} \mu^{3}$ cell $^{-1}$ frequently occurred in large numbers and were responsible for a large portion of the scatter in volumefrequency spectra (Fig. 4A). Quantitatively, multiple correlations among regression coefficients, buoyancy frequency and near-surface temperature and $\mathrm{NO}_{3}-\mathrm{N}$ concentration were computed (Table 3). In well-mixed waters these variables accounted for 2, 59 and $39 \%$, respectively, of the variance in $r$, but only the latter 2 were statistically significant $(p \leq 0.05)$. When surface and subsurface population maxima occurred, they accounted for $15,70,0 \%$, and $22,50,3 \%$, respectively, of the variance in $r$. Of these, only the former regression between $r$ and near-surface temperature was statistically significant. Thus, temperature more than buoyancy frequency and $\mathrm{NO}_{3}-\mathrm{N}$ concentration appeared to be related to volume-frequency structure of phytoplankton crops when diatoms dominated crops (Fig. 6).

Variations in values of the exponent $v$ for the power function model, applicable to all groups except the prebloom water, were generally small, and were not statistically related to any measured variable (Table 4). A 

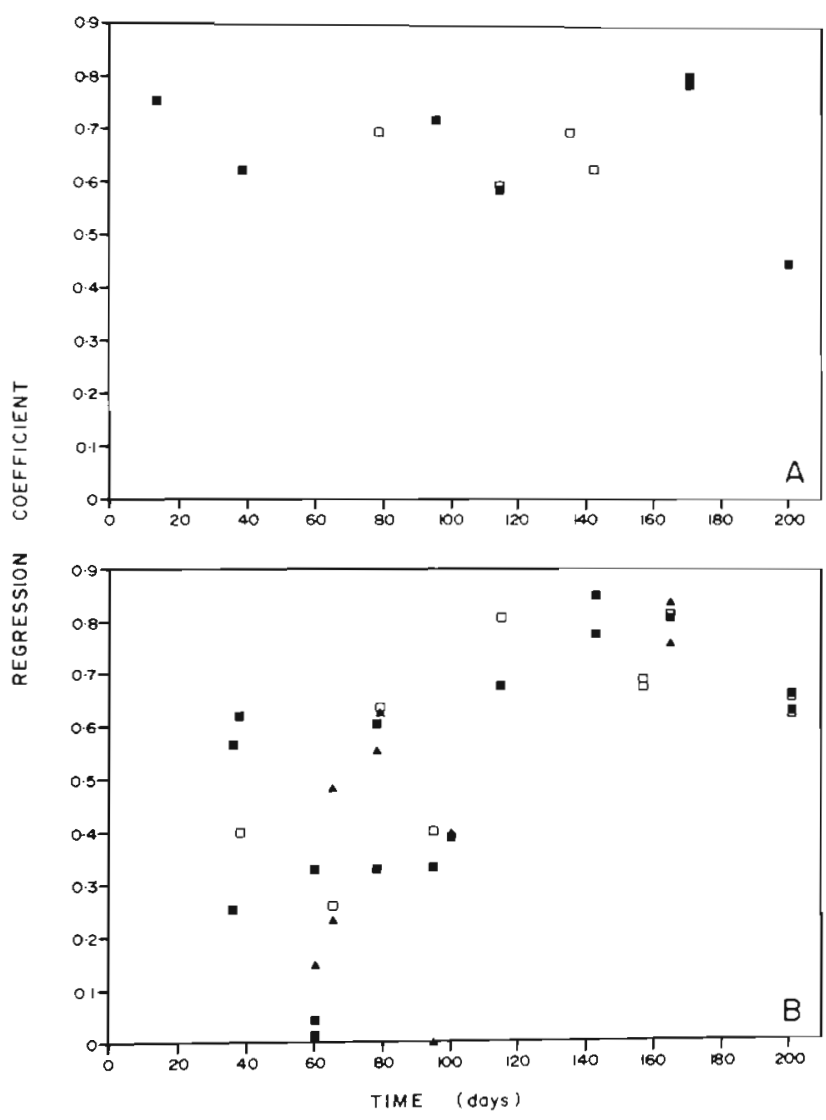

Fig. 5. Temporal variation after 1 Mar (time $=0$ d) in goodness-of-fit of cell-volume frequencies to a power function model for phytoplankton crops in (A) pre-bloom (a) and nutrient-stripped ( $\square$ ) waters with small percentages of diatoms, and (B) well-mixed ( $\mathbf{a}$ ) waters, and from population maxima in near-surface ( $\square$ ), and subsurface (₫) layers, all with large percentages of diatoms

Table 3. Degrees of freedom (DF), F-ratio $(F)$, probability $(p)$, and partial squared correlation coefficient $\left(r^{2}\right)$ for a step-wise regression analysis examining the dependency of the fit of volume-frequency spectra of phytoplankton to a power-function model on the variables (Var.), temperature $(T)$, nitrate concentration $\left(\mathrm{NO}_{3}-\mathrm{N}\right)$ and buoyancy frequency $(N)$ in wellmixed (1), surface bloom (2), and subsurface chlorophyl maximum (3) groups (Gr.) in near-surface (0 to $5 \mathrm{~m}$ ) waters. Results were omitted from the table when $F$-ratios were less than 0.025

\begin{tabular}{|cccccc|}
\hline Gr & Var. & DF & $F$ & $p$ & $r^{2}$ \\
\hline \multirow{2}{*}{1} & $N$ & 1,13 & 0.28 & 0.61 & 0.02 \\
& $T$ & 1,13 & 18.75 & 0.00 & 0.59 \\
& $\mathrm{NO}_{3}-\mathrm{N}$ & 1,13 & 8.3 & 0.01 & 0.39 \\
2 & $N$ & 1,9 & 1.63 & 0.23 & 0.15 \\
& $T$ & 1,9 & 20.84 & 0.00 & 0.70 \\
3 & $N$ & 1,4 & 1.12 & 0.35 & 0.22 \\
& $T$ & 1,4 & 3.95 & 0.12 & 0.50 \\
& $N^{*}-\mathrm{N}$ & 1,4 & 0.13 & 0.73 & 0.03 \\
\hline
\end{tabular}

grand mean for $v$ of $-0.92 \pm 0.03\left(\overline{\mathrm{x}} \pm \mathrm{s}_{\mathrm{x}}\right)$ was applicable to these categories. However, in pre-bloom water, $v$ was correlated to near-surface temperature (Table 3) and varied widely: from -1.4 to -0.66 becoming less negative as temperature increased (Fig. 7). This latter trend co-occurred with the appearance of relatively small volume celis of a flagellated chlorophyte, Pyramimonas sp., during late spring.

\section{DISCUSSION}

The volume-frequency structure of temperate neritic phytoplankton was not expected to correspond to a power-function model because the assumption of steady state would often be violated. The closest set of conditions which could potentially give rise to steady state were those found in Saanich Inlet during summer. At this time, nutrient concentrations were usually low and diatoms were not abundant (Table 1). Indeed, under these conditions, volume-frequency structures were closely fit by the model (Fig. 5A). Presumably, here the principal flow of mass would be from nanoflagellates to heterotrophic dinoflagellates and ciliated protozoa, which is a major portion of the food web found in open ocean ecosystems (e.g. Azam et al. 1983). At the same time, flux of particulates out of the euphotic zone should be small, a conclusion supported by the presence of low concentrations of chlorophyll a below the euphotic zone (Hobson 1983).

The model also closely fit phytoplankton structures whenever diatoms were not abundant and nutrient concentrations were large, conditions which occurred prior to the spring diatom increase in all waters examined (Fig. 5A). These results may be indicative of a steady state brought about by suboptimal irradiance and suboptimal seawater mixing that favoured flagellated cells over diatoms in crops. In Saanich Inlet, flagellated cells are probably consumed by ciliated protozoa (Takahashi \& Hoskins 1978) and calanoid copepods such as Pseudocalanus minutus, Paracalanus parvus (Koeller et al. 1979) and Metridia pacifica (results not shown). However, winter blooms of flagellated cells, which are not balanced by zooplankton grazing, can occur in Saanich Inlet (Whitney \& Wong 1984).

As was expected, volume-frequency data for phytoplankton assemblages poorly fit the power function model when diatoms such as Lauderia borealis, Skeletonema costatum, and Thalassiosira nordenskioldii dominated crops during spring (Fig. 5B). This could be the result of volume-scaled intrinsic division rates for these organisms that were higher than predicted by the results of other studies (e.g. Banse 1976). This explanation would be appropriate for either steady or 


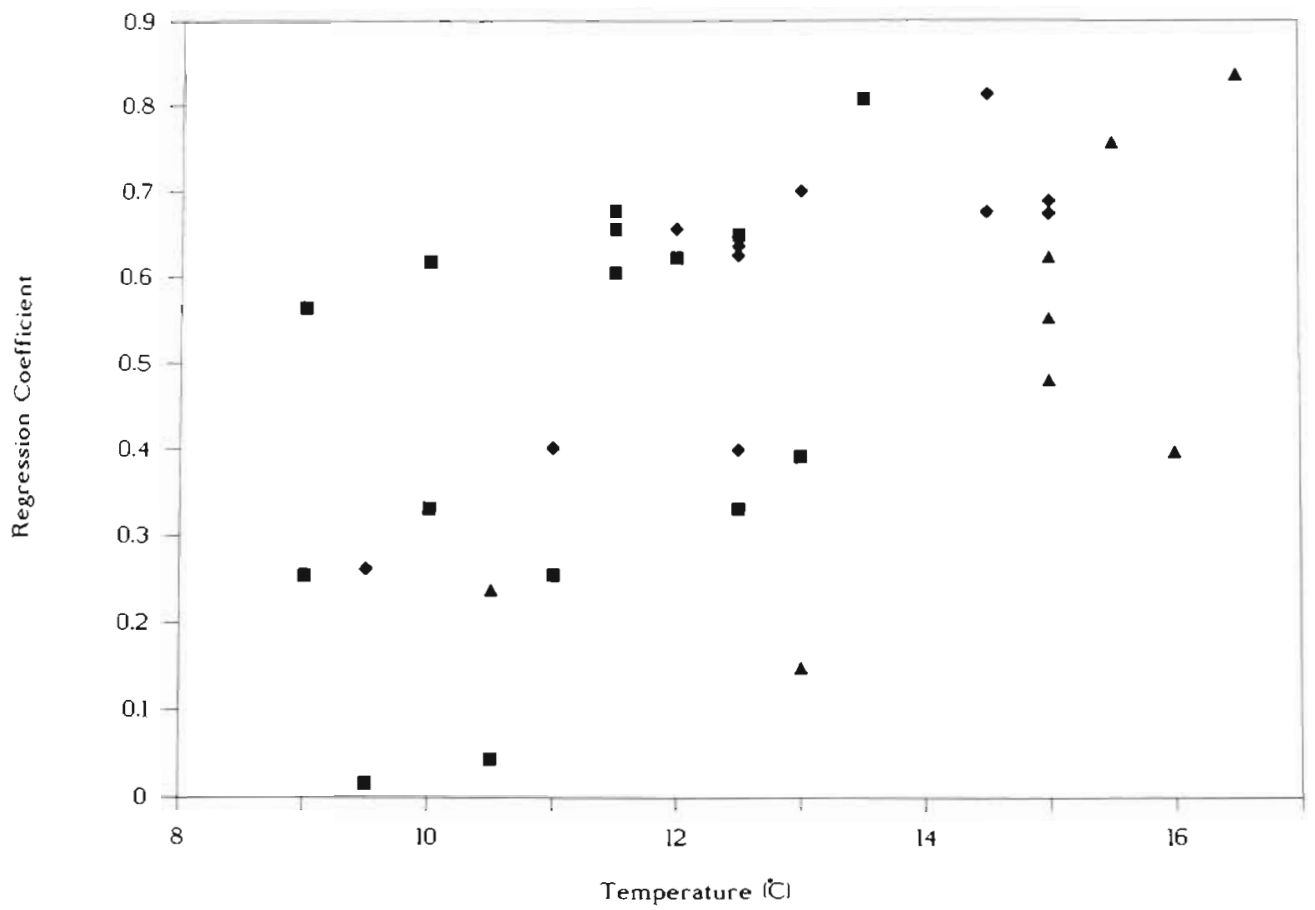

Fig. 6. Co-variation of near-surface $(0$ to $5 \mathrm{~m})$ seawater temperature and goodness-of-fit of cell volume frequencies to a power function model for diatom-dominated phytoplankton crops in well-mixed water ( $\bullet$ ) and concentrated in near surface ( $\bullet$ ) and subsurface (4) waters

Table 4. Degrees of freedom (DF), F-ratio $(F)$, probability $(p)$, and partial squared correlation coefficient $\left(r^{2}\right)$ for a step-wise regression analysis examining the dependency of the exponent of a power-function model on the variables (Var.), temperature $(T)$, nitrate concentration $\left(\mathrm{NO}_{3}-\mathrm{N}\right)$ and buoyancy frequency $(N)$ in pre-bloom (1), well-mixed (2), surface bloom (3), subsurface chlorophyll maximum (4) and stripped (5) categories (Gr.) in near-surface ( 0 to $5 \mathrm{~m}$ ) waters. Results were omitted from the table when $F$-ratios were less than 0.025

\begin{tabular}{|cccrcc|}
\hline Gr. & Var. & DF & $F$ & $p$ & $r^{2}$ \\
\hline \multirow{2}{*}{1} & $N$ & 1,3 & 1.24 & 0.35 & 0.29 \\
& $\mathrm{~T}$ & 1,3 & 12.74 & 0.04 & 0.81 \\
& $\mathrm{NO}_{3}-\mathrm{N}$ & 1,3 & 7.59 & 0.07 & 0.72 \\
2 & $\mathrm{~N}$ & 1,7 & 2.77 & 0.14 & 0.28 \\
& $\mathrm{~T}$ & 1,7 & 0.24 & 0.64 & 0.03 \\
& $\mathrm{NO}_{3}-\mathrm{N}$ & 1,7 & 2.00 & 0.20 & 0.22 \\
3 & $\mathrm{~N}$ & 1,6 & 0.15 & 0.71 & 0.02 \\
& $\mathrm{NO}_{3}-\mathrm{N}$ & 1,6 & 0.87 & 0.39 & 0.13 \\
4 & $\mathrm{~N}$ & 1,4 & 0.20 & 0.68 & 0.05 \\
5 & $\mathrm{NO}_{3}-\mathrm{N}$ & 1,2 & 1.36 & 0.36 & 0.40 \\
& & & & &
\end{tabular}

non-steady state conditions, but I have found support neither for nor against the idea in the literature. Alternate explanations include differential injection of resting spores of the spring bloom diatoms into the euphotic zone, avoidance of these organisms by herbivores, and absence of specific herbivores. These all lead to the assumption of non-steady state conditions, supported by observations of accumulations of large biomasses of near-surface phytoplankton during spring in Saanich Inlet (Hobson 1981, 1983) and the coincident presence of chlorophyll $a$ at depths deeper than the euphotic zone (Hobson 1983). Also, large populations of the omnivorous copepod Calanus pacificus begin active feeding in Saanich Inlet after the peak of the diatom bloom (K. Burns unpubl.) and population sizes of the omnivorous euphausiid Euphausia pacifica expand in May reaching a maximum in the Inlet in June (Guest 1979). Thus, 'spikes' on volume-frequency spectra could develop in the absence of these grazers.

Expansion of grazing pressure exerted by Calanus pacificus and Euphausia pacifica could covary with increasing water temperature, and if so, would be consistent with the observed increase in balance between measured volume-frequency distributions for phytoplankton crops and those predicted by the powerfunction model as near-surface temperature increased (Fig. 6). It seems unlikely that increasing temperature was the cause of enhanced predictability because values of temperature varied among the different waters containing large crops of diatoms (Fig. 2).

The exponent ( $v$ ) for the power function model was relatively constant with a mean value of -0.92 when volume-frequency data fit the model and either diatoms or flagellated cells in nutrient-stripped water dominated phytoplankton biomasses. This value was 


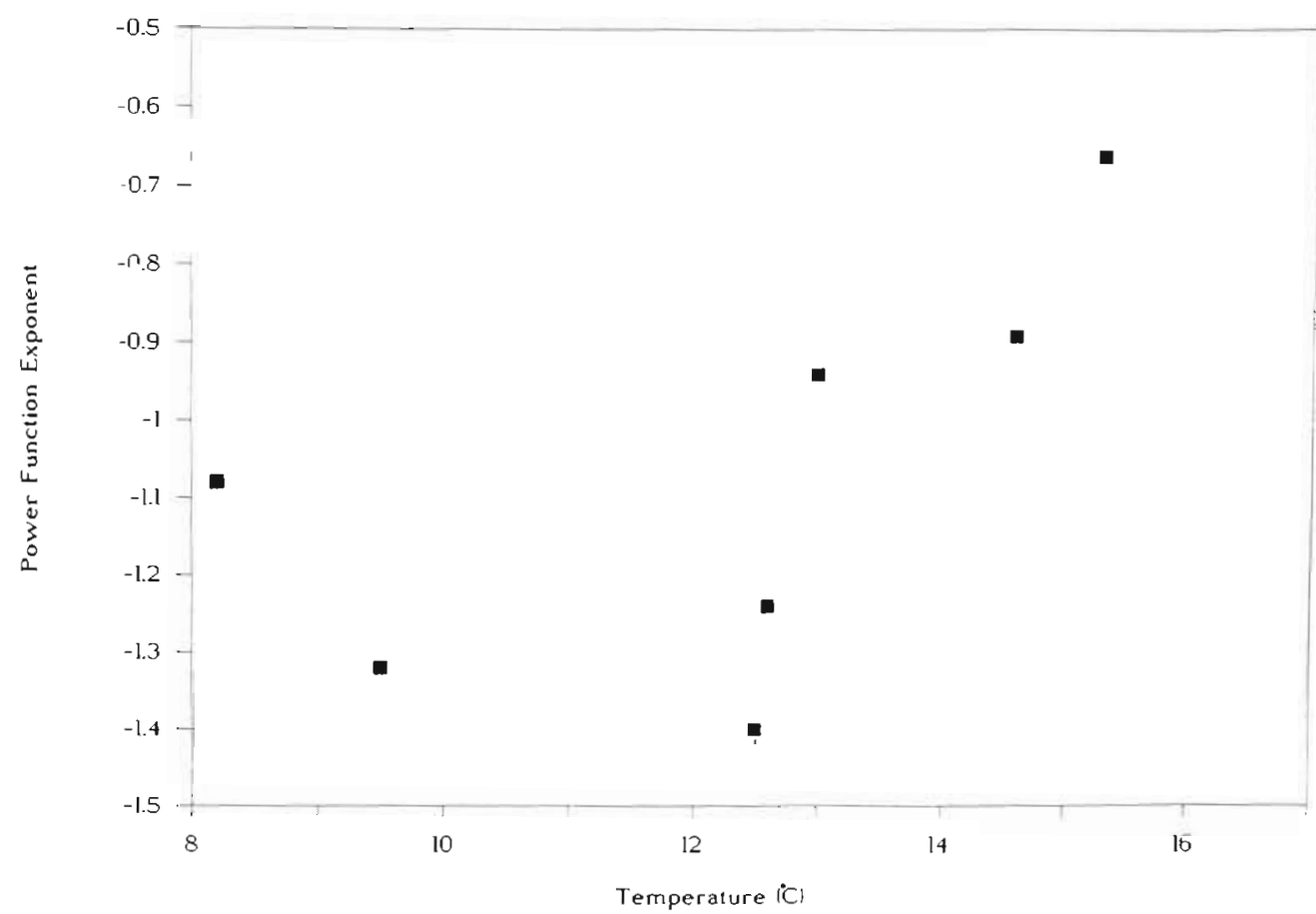

Fig. 7. Co-variation of near-surface $(0$ to $5 \mathrm{~m})$ seawater temperature and the exponent of a power function model predicting cellvolume frequencies of flagellate-dominated phytoplankton crops

less negative than -1.22 predicted by Platt \& Denman (1978) with the expression:

$$
b=-(1-x+\alpha A+q)
$$

where $x=$ slope for biomass-scaled turnover time (0.28) (from Fenchel 1974); $\alpha=$ proportionality constant for the biomass-scaled turnover time $\left(2 \times 10^{-7} \mathrm{~s}^{-1}\right) ; A=$ the proportionality constant for biomass-scaled metabolic rate $\left(2.5 \times 10^{6} \mathrm{~s}\right)$ derived by Platt \& Denman (1978) from data presented by Fenchel (1974) for heterothermic organisms; $q=$ an exponent for feeding efficiency, the value of which is small compared to those of the other exponents and can be ignored (Platt \& Denman 1978). I have computed here a value of $b$, assuming that for algal cells $x$ is closer to 0.25 (Banse 1976) than 0.28 and $\alpha A$ applicable to unicellular organisms is 0.1 rather than 0.5 (Platt \& Denman 1978). Thus, the theoretical slope is -0.85 , close to the measured mean value, which also was similar to most values derived for lake phytoplankton (Sprules \& Munawar. 1986). This concordance between measured and theoretical values supports the view that intrinsic division rates of wild algal cells are volume scaled (Banse 1976), although results of an exhaustive literature review of laboratory derived values suggested otherwise (Banse 1982). Intrinsic rates perhaps may not be estimatable from laboratory experiments where environmental variables often, by necessity, are controlled at abnormal levels.
The exponent for crops in pre-bloom water, where flagellated cells dominated small phytoplankton biomasses, became less negative as temperature increased (Fig. 7). This correlation suggested a shift of cells from smaller to larger cellular volumes, which may have been caused by the presence of relatively large Pyramimonas sp. cells during late spring.

Results of the present study extend the use of a power function model to predict volume-frequency spectra of organisms from open-ocean low-nutrient environments (Platt et al. 1984, Rodriguez \& Mullin 1986) and relatively nutrient-rich lakes (Sprules \& Munawar 1986) to temperate neritic ecosystems where phytoplankton crops are dominated either by flagellated cells or by diatoms outside the spring diatom bloom. However, caution must be exercised because values of the exponent can vary. For example, the exponent for volume-frequencies of flagellate assemblages prior to blooms became less negative with time. Also, Sprules \& Munawar (1986) reported a change to more negative values when total phosphorus and chlorophyll a declined below critical levels in lakes. This change could be expected if cells are autotrophic and cellular volumes decline as nutrient concentrations and rates of vertical diffusion decrease, a correlation implicit in data presented by Eppley et al. (1969). However, this was not observed for volumefrequency distributions of flagellated cells in $\mathrm{NO}_{3}-\mathrm{N}$ stripped water, perhaps because of either the presence 
of adequate supplies of $\mathrm{NH}_{4}-\mathrm{N}$ or the presence of potentially heterotrophic large dinoflagellates, or both

A final caution in using mass-frequency spectra should be noted. Models are derived assuming steady state between primary production of new cells and subsequent consumption of those cells. However authors of plankton studies demonstrating mass-frequency spectra with constant slopes have presumed the occurrence of steady state conditions (Rodriguez \& Mullin 1986, Sprules \& Munawar 1986). This presumption is not necessarily warranted unless an independent proof of steady state is provided, which will be particularly difficult in neritic waters with tidal currents causing variable mixing regimes.

Acknowledgements. I thank Drs K. Denman and H. Barclay for constructive criticisms of this manuscript and Dr D. Mackas for bringing the paper by Ricker (1973) to my attention. Also, I thank the officer and crew of the Marine Sciences Service Vessel 'John Strickland' for providing a sampling platform. In addition, I thank Dr R. Brinkhurst and the Institute of Ocean Sciences, Patricia Bay, Sidney, B. C., Government of Canada, Fisheries and Oceans for space used during this study. Research was supported by operating and strategic grants provided by the Natural Sciences and Engineering Research Council of Canada, and by a research grant from the University of Victoria.

\section{LITERATURE CITED}

Azam, F., Fenchel, T., Field, J. G., Gray, J. S., Meyer-Reil, L. A., Thingstad, F. (1983). The ecological role of watercolumn microbes in the sea. Mar. Ecol. Prog. Ser. 10: $257-263$

Banse, K. (1976). Rates of growth, respiration and photosynthesis of unicellular algae as related to cell size - a review. J. Phycol. 12: 135-140

Banse, K. (1982). Cell volumes, maximal growth rates of unicellular algae and ciliates, and the role of ciliates in the marine pelagial. Limnol. Oceanogr 27: 1059-1071

Borgmann, U. (1982). Particle-size-conversion efficiency and total animal production in pelagic ecosystems. Can. J. Fish. Aquat. Sci. 39: 668-674

Eppley, R. W., Rogers, J. N., McCarthy, J. J. (1969). Halfsaturation constants for uptake of nitrate and ammonium by marine phytoplankton. Limnol. Oceanogr. 14: 912-920

Fenchel, T. (1974). Intrinsic rate of natural increase: the relationship with body size. Oecologia 14: 317-326

Guest, K. P. (1979). A nitrogen budget for Saanich Inlet, B. C. B. Sc. thesis, University of Victoria

Hobson, L. A. (1981). Seasonal variations in maximum photosynthetic rates of phytoplankton in Saanich Inlet, Vancouver Island, British Columbia. J. exp. mar. Biol. Ecol. 52: $1-13$

Hobson, L. A. (1983). Phytoplankton crops, bacterial metabolism and oxygen in Saanich Inlet, a fjord in Vancouver Island, British Columbia. Sed. Geol. 36: 117-130

Hobson, L. A., Menzel, D. W., Barber, R. T. (1973). Primary productivity and sizes of pools of organic carbon in the mixed layer of the ocean. Mar. Biol. 19: 298-306

Jeffrey, S. W., Humphrey, G. F. (1975). New spectrophotometric equations for determining chlorophylls $a, b, c_{1}$ and $c_{2}$ in higher plants, algae and natural phytoplankton. Biochem. Physiol. Pflanz. 167: 191-194

Koeller, P. A., Barwell-Clarke, J. E., Whitney, F., Takahasi, M. (1979). Winter conditions of marine plankton in Saanich Inlet, B. C. Canada. III. Mezo-zooplankton. J. exp. mar. Biol. Ecol. 37: 161-174

Lorenzen, C. J. (1967). Determination of chlorophyll and pheo-pigments: spectrophotometric equations. Limnol. Oceanogr 12: 343-346

McCarthy, J. J. (1970). A urease method for urea in seawater. Limnol. Oceanogr. 15: 309-313

Parsons, T. R., Stronach, J., Borstadt, G. A., Louttit, G., Perry, R. I. (1981). Biological fronts in the Strait of Georgia, British Columbia, and their relation to recent measurements of primary productivity. Mar. Ecol. Prog. Ser. 6: 237-242

Platt, T., Denman, K. (1977). Organization in the pelagic ecosystem. Helgoländer wiss. Meeresunters. 30: 575-581

Platt, T., Denman, K. (1978). The structure of pelagic ecosystems. Rapp. P.-v. Réun. Cons. int. Explor. Mer 173: 60-65

Platt, T., Lewis, M., Geider, R. (1984). Thermodynamics of the pelagic ecosystem: elementary closure conditions for biological production in the open ocean. In: Fasham, M. J. R. (ed.) Flows of energy and materials in marine ecosystems. Proc. NATO Adv. Res. Inst., Plenum, New York, p. 49-84

Ricker, W. E. (1973). Linear regressions in fishery research. J. Fish. Res. Bd Can. 30: 409-434

Rodriguez, J., Mullin, M. M. (1986). Relation between biomass and body weight of plankton in a steady state oceanic ecosystem. Limnol. Oceanogr 31: 361-370

Sheldon, R. W., Parsons, T. R. (1967). A practical manual on the use of the Coulter counter in marine sciences. Coulter Electronics, Toronto

Sheldon, R. W., Prakash, A., Sutcliffe, W. H., Jr. (1972). The size distribution of particles in the ocean. Limnol. Oceanogr. 17: 327-340

Solorzano, L. (1969). Determination of ammonia in natural waters by the phenolhypochlorite method. Limnol. Oceanogr. 14: 799-801

Sprules, W. G., Munaware, M. (1986). Plankton size spectra in relation to ecosystem productivity, size and perturbation. Can. J. Fish. Aquat. Sci. 43: 1789-1794

Strathmann, R. R. (1967). Estimating the organic carbon content of phytoplankton from cell volume or plasma volume. Limnol. Oceanogr. 12: 411-418

Strickland, J. D. H., Parsons, T R. (1972). A practical handbook of seawater analysis (2nd ed.). Bull. Fish. Res. Bd Can. 167

Takahashi, M., Hoskins, K. D. (1978). Winter conditions of marine plankton populations in Saanich Inlet, B. C. Canada. II. Micro-zooplankton. J. exp. mar. Biol. Ecol. 32: $27-37$

Turmer, J. S. (1981). Small-scale mixing processes. In: Warren, B. A., Wunsch, C. (eds.) Evolution of physical oceanography. MIT Press, Cambridge, p. 236-262

Whitney, F. A., Wong, C. S. (1984). Carbon cycling in the shallow waters of Saanich Inlet. In: Juniper, S. K., Brinkhurst, R. O. (eds.) Proceedings of a multidisciplinary symposium on Saanich Inlet, 2 Feb 1983. Can. Tech. Rept Hydrogr. Ocean Sci. 38: 45-47 